CZASOPISMO INŻYNIERII LADDOWEJ, ŚRODOWISKA I ARCHITEKTURY JOURNAL OF CIVIL ENGINEERING, ENVIRONMENT AND ARCHITECTURE JCEEA, t. XXXII, z. 62 (3/II/15), lipiec-wrzesień 2015, s. 209-220

\author{
Pavlo KRAINSKYI ${ }^{1}$ \\ Roman KHMIL ${ }^{2}$ \\ Zinoviy BLIKHARSKIY ${ }^{3}$
}

\title{
THE STRENGTH OF REINFORCED CONCRETE COLUMNS, STRENGTHENED BY REINFORCED CONCRETE JACKETING UNDER LOADING
}

Reinforced concrete (RC) jacketing is the most widespread method of columns strengthening. The design of such strengthening requires consideration of additional factors. Among them is the impact of the load supported by the existing structure during strengthening on the future performance of the strengthened structure. Determination of the impact of that factor is the main objective of this research. To achieve this RC column specimens were strengthened after preliminary loading to different levels and tested to failure. All specimens had identical geometrical and mechanical characteristics and were tested as pinned columns subjected to eccentric loading. Different load values applied prior to strengthening represented the only variable parameter. During tests dial indicators were used to measure linear deformation of reinforcement and concrete. Measurements were taken from jacketing and strengthened columns. Deflections along the column length as well as crack development were also monitored. RC jacketing is a very effective strengthening method that allowed us to achieve up to $290 \%$ of strength increase. Strengthened columns appeared to work as monolithic structures. No displacements, cracks or adherence loss between columns and jacketing was noticed, even though no interface preparation methods were used to increase bonding between the new concrete and the column. Experimental strength of test specimens was close to calculated values. Maximum deviation equaled $10 \%$.

Keywords: reinforced concrete, columns, jacketing, design.

\footnotetext{
${ }^{1}$ Pavlo Krainskyi postgraduate student; Lviv Polytechnic National University; Ukraine, 79013, Lviv, S. Bandera Street, 12; pavlinij@i.ua.

2 Author for correspondence: Roman Khmil PhD associate professor; Lviv Polytechnic National University; Ukraine, 79013, Lviv, S. Bandera Street, 12; roman_hl@ukr.net.

${ }^{3}$ Zinoviy Blikharskyy professor; Lviv Polytechnic National University; Ukraine, 79013, Lviv, S. Bandera Street, 12., blikharskyy@ukr.net
} 


\section{Introduction}

In the design of strengthening of existing buildings and their structural members, engineers have to consider a number of factors that do not arise in the design of new structures. These factors include: deviations from the project plans during construction, damage and deformation throughout the exploitation period, changes in constraints of some structural members, changes in service loads application scheme, stress-strain state of structural members at the time of strengthening, etc. In practice, an opportunity to completely unload a structural member before strengthening is very rare. Even if one removes all the service load, the structure will still support its own weight and the weight of the upper floors of the building. Therefore, in this article, we focus our attention on the study of the impact of the load supported by the existing structure during strengthening on the future performance of the structure after strengthening.

The majority of civil and industrial buildings in Ukraine were constructed using precast reinforced concrete members. That's why, in this research, experimental studies were performed on RC column specimens. Considering that the increase of $\mathrm{RC}$ member's cross section is the most widespread type of strengthening, RC jacketing was chosen as strengthening method under study. RC jacketing proved to be very effective strengthening method as we can see from different studies $[3,4,5]$. In some cases this method allows to achieve a monolithic behavior of the composite element without any additional surface preparation [3] which is very convenient.

Based on the above, the main objectives of the work were to:

1. Experimentally determine the parameters of strength and deformability of strengthened RC column specimen.

2. Determine the impact of stress state of the specimen at the time of strengthening on its future performance.

3. Compare experimental results with theoretically calculated values.

\section{Experimental program}

\subsection{Design of test specimens}

For this study eight reinforced concrete column specimens were designed and manufactured. The columns were $2200 \mathrm{~mm}$ long, with cross section dimensions equal $180 \mathrm{~mm}$ by $140 \mathrm{~mm}$. On both sides columns had cantilever sections to create eccentrically applied loading. Four $12 \mathrm{~mm}$ rebars were used as longitudinal reinforcement (reinforcement percentage equaled $1.8 \%$ ) and $6 \mathrm{~mm}$ wire was used for ties with $200 \mathrm{~mm}$ spacing. Drawings of test specimens are presented in Figure 1.

Special fasteners were welded to longitudinal reinforcement of the test specimens at the middle section (see Figure 2). These fasteners were used to attach dial indicators to measure linear deformations of reinforcement. Same fasteners were welded to jacketing reinforcement at midsection. 


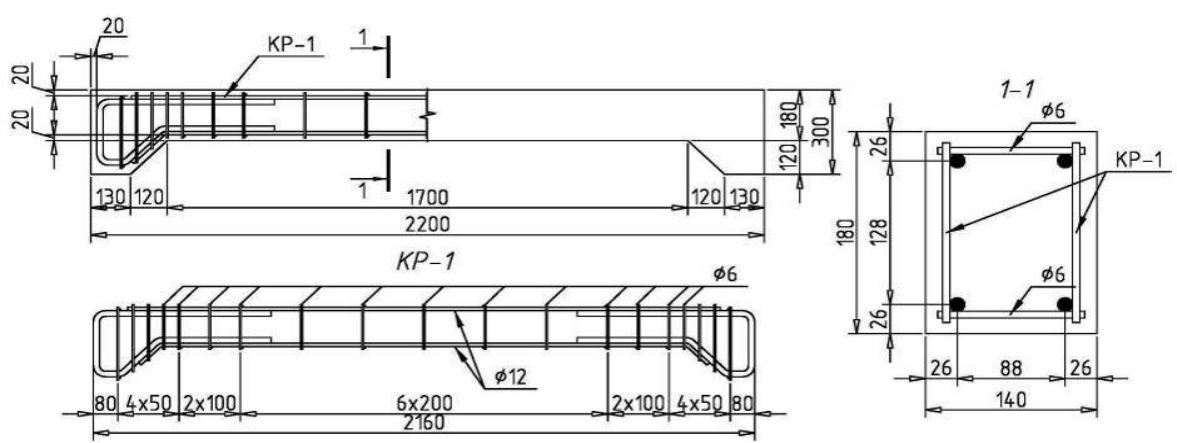

Fig. 1. Test specimens

Rys. 1. Próbka do badań

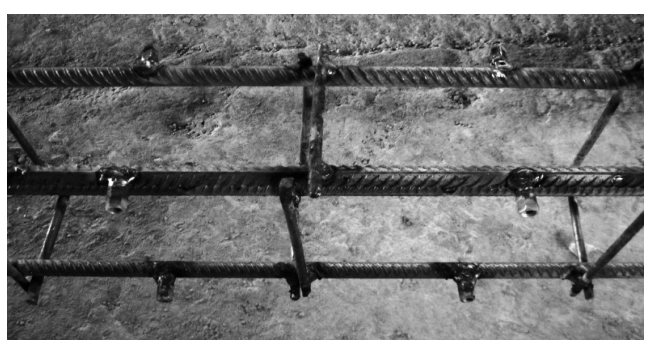

Fig. 2. Fasteners for dial indicators

Rys. 2. Łączniki do mocowania wskaźników

Cross section dimensions of a strengthened column were $260 \mathrm{~m}$ by $200 \mathrm{~mm}$. The length or RC jacketing equaled $1700 \mathrm{~mm}$. Four $10 \mathrm{~mm}$ rebar were used as additional longitudinal reinforcement (reinforcement percentage equaled $1.17 \%$ ) and $6 \mathrm{~mm}$ wire was used for ties with $200 \mathrm{~mm}$ spacing. Drawings of test specimens after strengthening are presented in Figure 3.

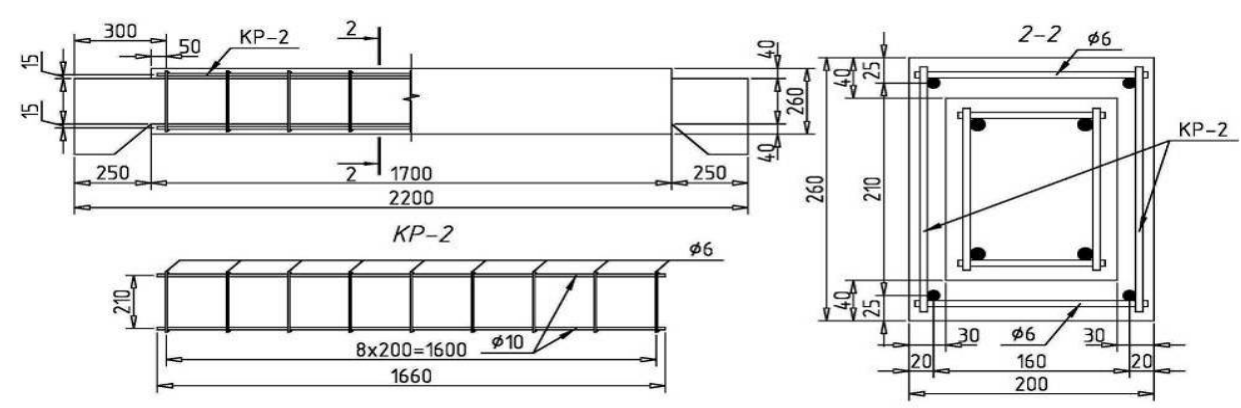

Fig.3. Test specimens after strengthening

Rys. 3. Próbka do badań po wzmocnieniu 


\subsection{Test program}

Two specimens (C-1 and C-2) were tested to failure without strengthening, which allowed to determine their actual limit strength. We define limit strength as a load level when yielding occurs in the reinforcement of the column. Although structural collapse of the specimen occurs later, we still consider reinforcement yield as a limit state, since immediately after it, the specimen achieves excessive deflections and crack widths and becomes completely unsafe for normal exploitation.

The remaining six specimens were strengthened as follows. Two specimens (SC-1-0.0 and SC-2-0.0) were strengthened without prior loading and then tested to failure. Specimens SC-3-0.3 and SC-4-0.3 were loaded to $30 \%$ of their limit strength, strengthened and tested to failure. Specimens SC-5-0.5 and SC-6-0.5 were loaded to $50 \%$ of their limit strength, strengthened and tested to failure.

In specimens labeling letter " $\mathrm{C}$ " stands for column and letter " $\mathrm{S}$ " for strengthened. The number after the first hyphen represents an ordinal number of a column. A decimal number at the end indicates loading level before strengthening.

\subsection{Material properties}

Mechanical characteristics of steel reinforcement were obtained from tensile testing results. Four specimens of $12 \mathrm{~mm}$ rebar used as the column's longitudinal reinforcement were tested. The average values of reinforcement characteristics were determined to be as follows. Rupture strength of $722.8 \mathrm{MPa}$, a yield stress of $636.9 \mathrm{MPa}$ and yield strain of $0.3 \%$. Young's modulus equaled $211 \mathrm{GPa}$.

Another four specimens of $10 \mathrm{~mm}$ rebar which were used as jacketing longitudinal reinforcement produced the following average values: rupture strength of $701.5 \mathrm{MPa}$, a yield stress of $610.7 \mathrm{MPa}$ and yield strain of $0.29 \%$. Young's modulus equaled $210 \mathrm{GPa}$.

Three specimens of $6 \mathrm{~mm}$ wire which was used for ties in columns as well as in RC jacketing showed average rupture strength of $529.2 \mathrm{MPa}$ and a yield stress of 362.2MPa.

A columns' concrete average compressive cube strength at 28 days was $37.7 \mathrm{MPa}$.

An average compressive cube strength of $\mathrm{RC}$ jacketing at 28 days was $40.4 \mathrm{MPa}$ and $39.9 \mathrm{MPa}$ for specimens SC-1-0.0 and SC-2-0.0 respectively; $40.0 \mathrm{MPa}$ and $36.6 \mathrm{MPa}$ for specimens SC-3-0.3 and SC-4-0.3; and $39.0 \mathrm{MPa}$ and 37.5MPa for specimens SC-5-0.5 and SC-6-0.5. 


\subsection{Strengthening and testing procedure}

Strengthening process had begun after columns were loaded to a planned level according to the test program. Columns were kept under constant load. Strengthening started with fastening of jacketing reinforcement firmly in position to prevent displacement during concrete pouring (see Figure 4).

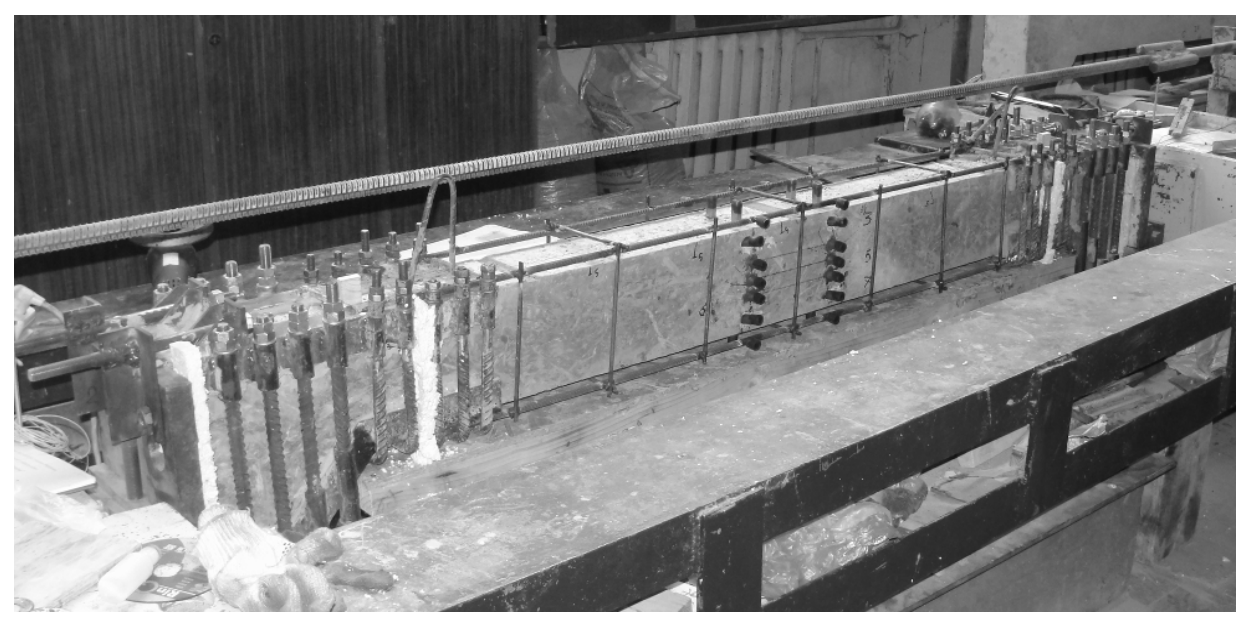

Fig. 4. Installation of jacketing reinforcement

Rys. 4. Montaż zbrojenia otuliny

No interface preparation methods were used to increase bonding between the new concrete and the column. After reinforcement installation, forms were fixed around the column (see Figure 5). Then concrete with small-sized limestone aggregate (less then $10 \mathrm{~mm}$ ) and superplasticizer was poured into the form and left for curing for 28 days.

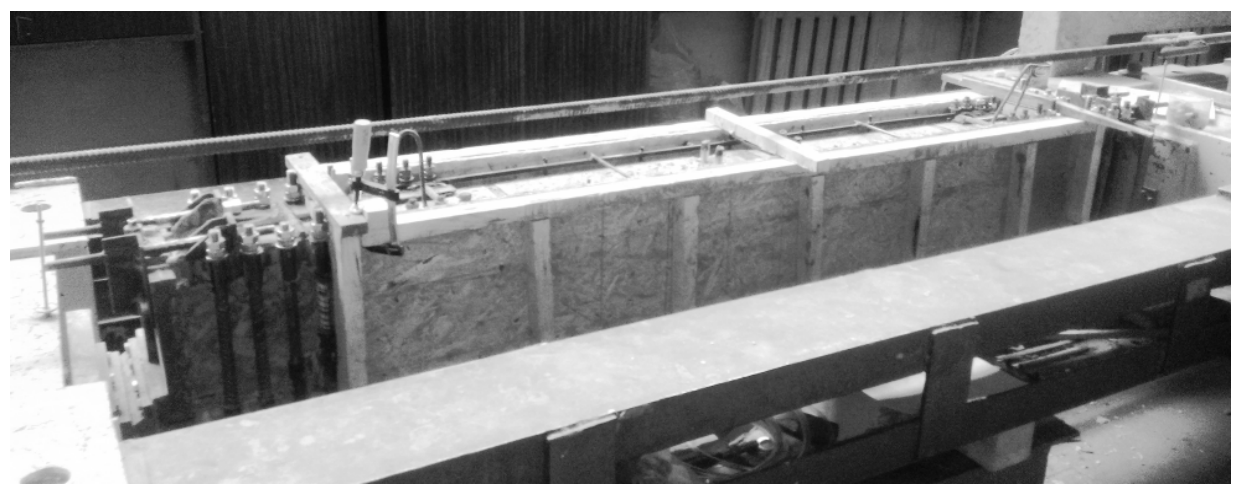

Fig. 5. Column before concrete pouring

Rys. 5. Słup przed zalaniem betonu 
Specimens were tested according to a procedure described in [2]. This procedure is commonly used in Lviv Polytechnic University for column compression tests. A stand used for compression tests is shown in Figure 6.

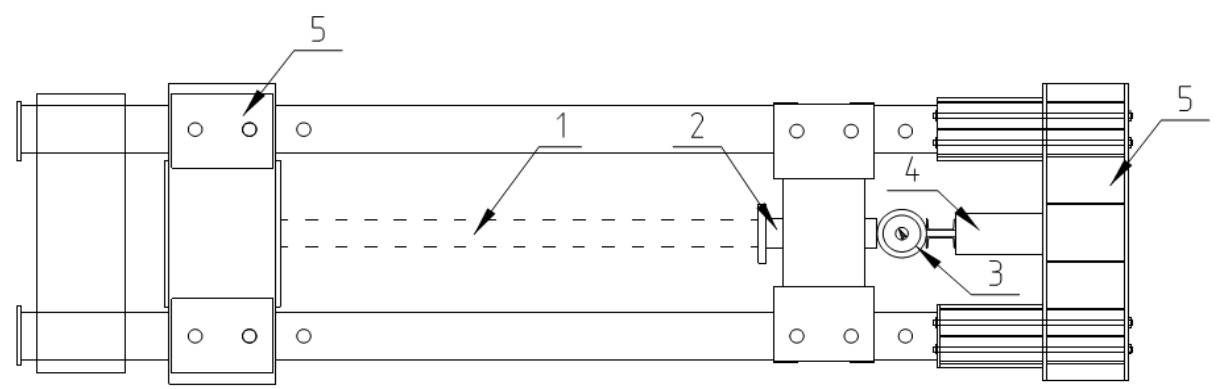

Fig. 6. Compression test stand. 1- tested specimen ; 2- plunger; 3- ring dynamometer; 4- hydraulic jack; 5- rigid steel beam

Rys. 6. Stanowisko do badania na ściskanie. 1- badana próbka; 2 - tłok; 3 - dynamometr kabłonkowy; 4 - siłownik hydrauliczny; 5 - sztywna belka stalowa

All specimens were tested as eccentrically loaded pinned columns. For every column eccentricity equaled $150 \mathrm{~mm}$. Load to the columns was applied incrementally (one ton at a time). Measurements from gauges were taken after each increment. In total, there were 11 dial indicators (Di) and 5 deflectometers (Def) on unstrengthened columns and 24 dial indicators and 5 deflectometers on strengthened ones. Positions of the gauges on test specimens are shown on Figures 7 and 8.

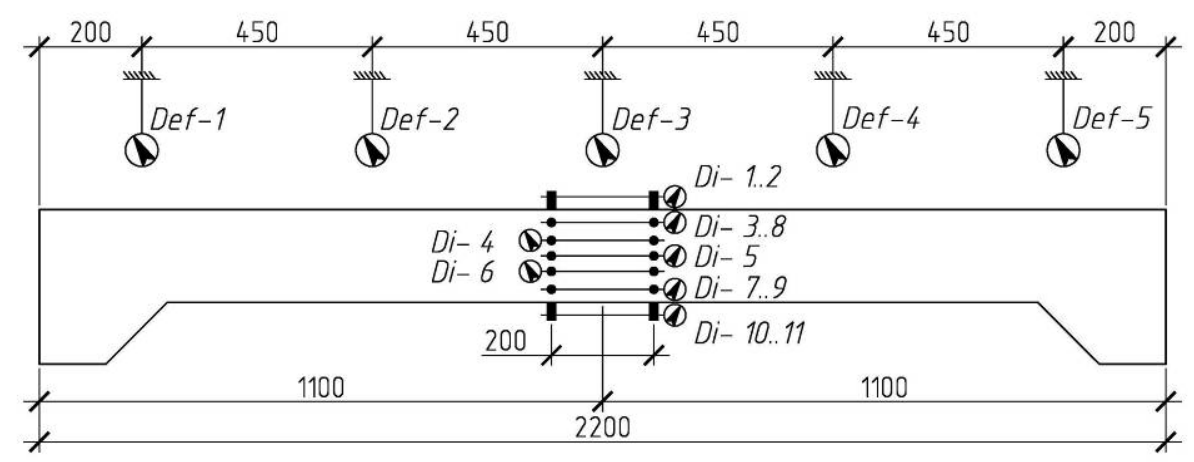

Fig. 7. Gauges position on unstrengthened columns

Rys. 7. Rozmieszczenie urządzeń pomiarowych na słupie bez wzmocnienia 


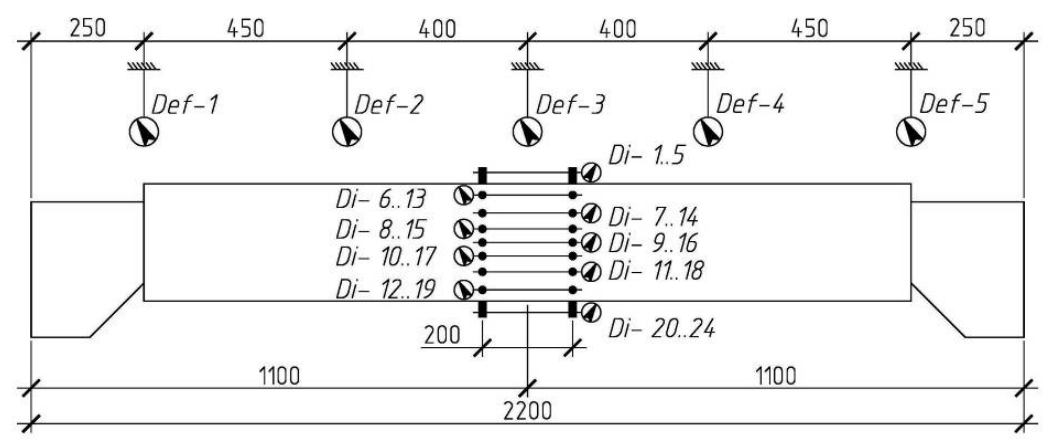

Fig. 8. Gauges position on strengthened columns

Rys. 8. Rozmieszczenie urządzeń pomiarowych na słupie wzmocnionym

Dial indicators were used to measure linear deformation of reinforcement and concrete. These measurements were used to calculate the reinforcement strain and concrete strain along the cross section's height.

\section{Results and analysis}

\subsection{Unstrengthened columns}

Columns C-1and C-2 failed in a flexural manner at midsection. Reinforcement yield occurred at an average load of $165.7 \mathrm{kN}$ (see Figure 9).
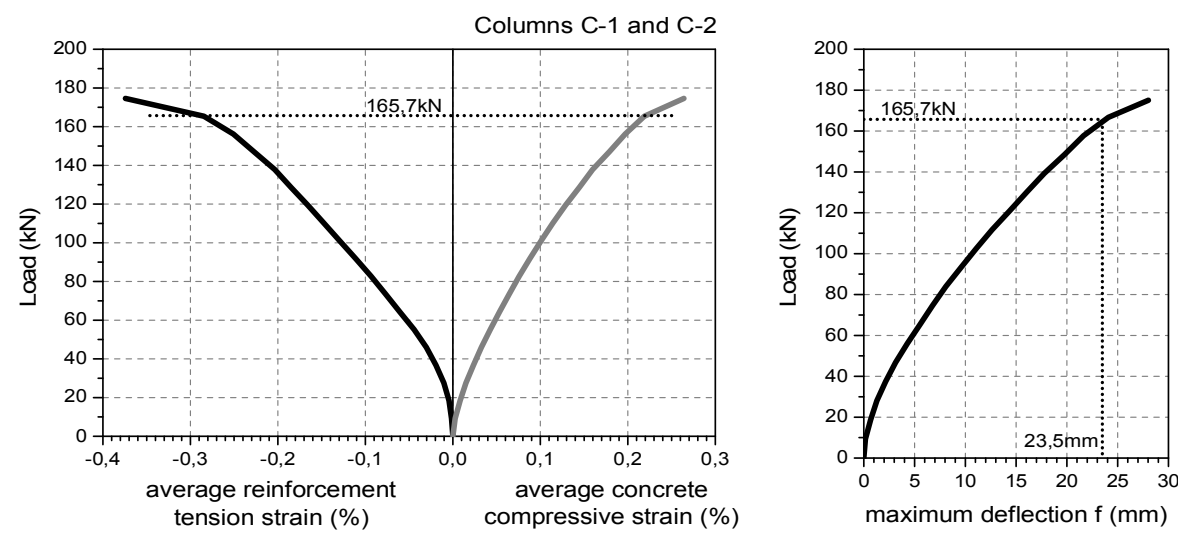

Fig. 9. Strain and maximum deflection plots

Rys. 9. Wykres odkształceń i maksymalnych ugięć

The first $0.05 \mathrm{~mm}$ wide cracks appeared when columns reached $\approx 47 \%$ of their limit strength and developed up to $0.3-0.4 \mathrm{~mm}$ until reinforcement yield. 
Immediately after that, a large increase in crack width and deflection happened followed by the concrete crashing at a compressed face of the columns (see Figure 10).
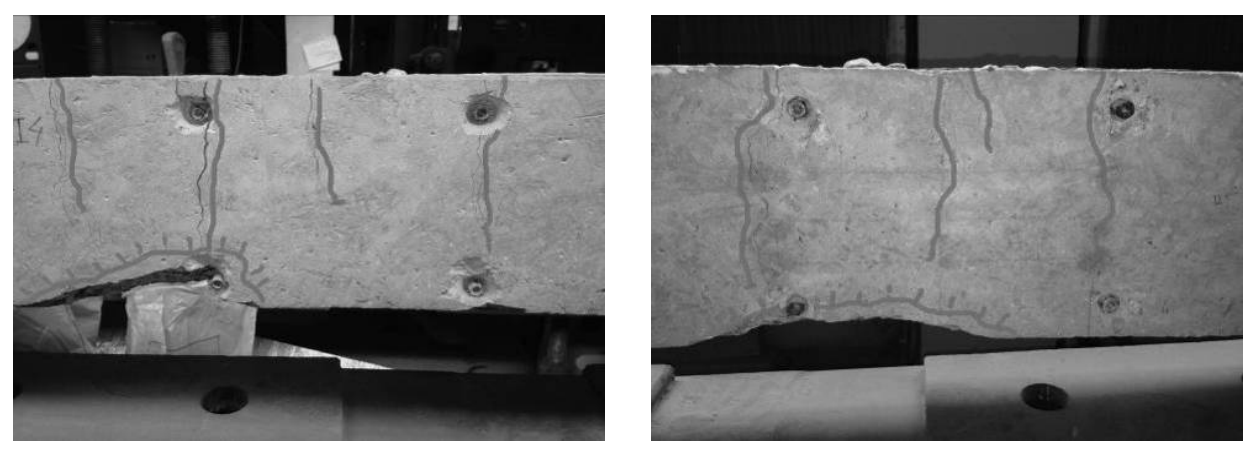

Fig. 10. Columns C-1 and C-2

Rys. 10. Słupy C1 i C2

\subsection{Strengthened columns}

All strengthened columns were tested not sooner than 28 days after concrete pouring. They all showed similar behavior to unstrengthened columns in terms of failure mode that is, in flexural manner (see Figure 11).
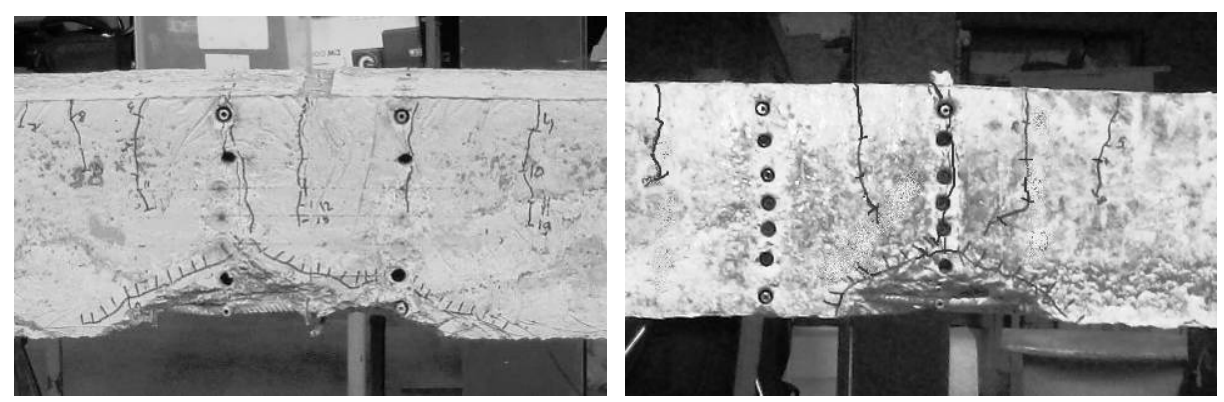

Fig. 11. Columns CS-2-0.0 and CS-5-0.5

Rys. 11. Słupy CS-2-0.0 i CS-5-0.5

In every strengthened specimen, a yield of jacketing reinforcement occurred sooner than a yield of column reinforcement. We consider a load when the yield in both reinforcement layers occurs as a limit strength of the specimen. For columns SC-1-0.0 and SC-2-0.0, average limit strength was $480.5 \mathrm{kN}$; for columns SC-3-0.3 and SC-4-0.3 - 460.9kN; for columns SC-5-0.5 and SC-6-0.5-441.3kN (see Figures 12, 13 and 14). 


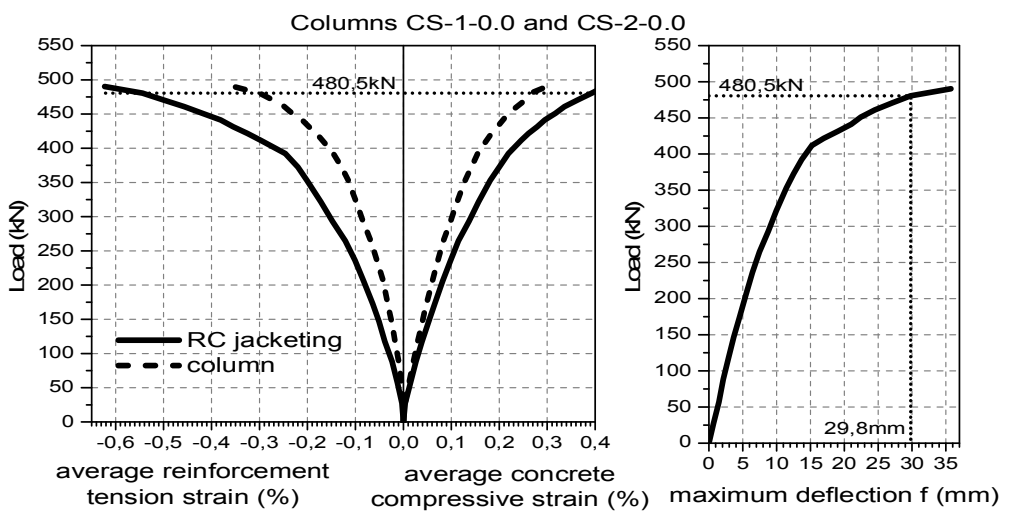

Fig. 12. Strain and maximum deflection plots

Rys. 12. Wykres odkształceń i maksymalnych ugięć

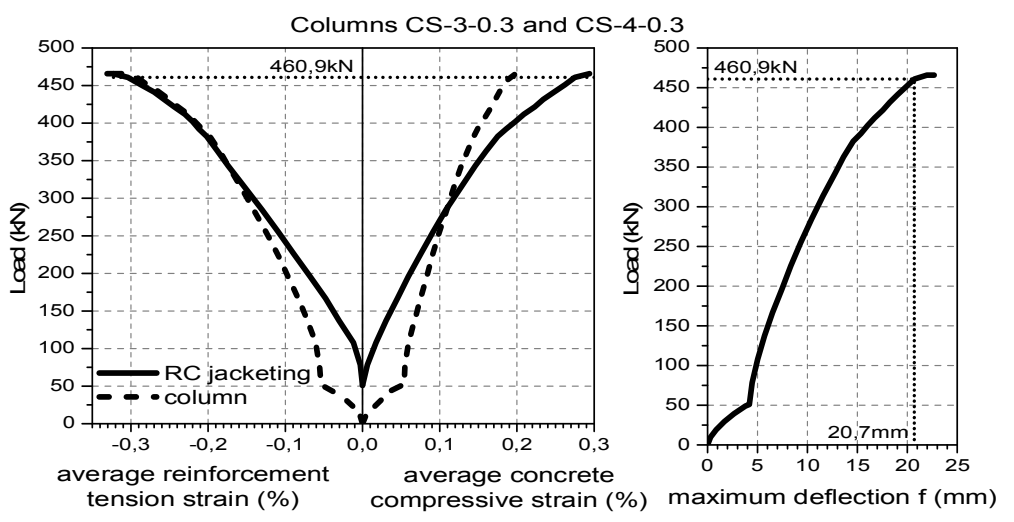

Fig. 13. Strain and maximum deflection plots

Rys. 13. Wykres odkształceń i maksymalnych ugięć

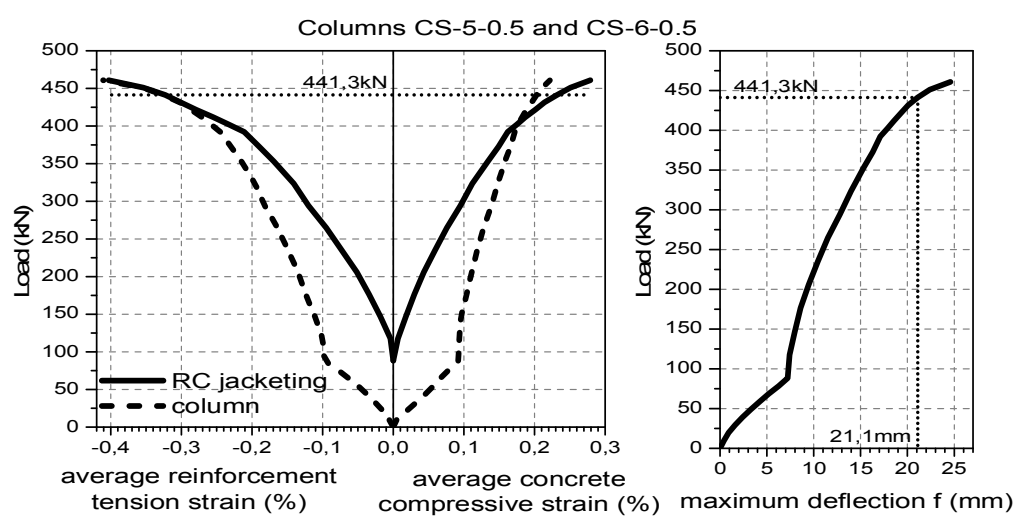

Fig. 14. Strain and maximum deflection plots

Rys. 14. Wykres odkształceń i maksymalnych ugięć 
The later a column was strengthened, the later the cracks started to appear. On specimens SC-1-0.0 and SC-2-0.0, cracks with $0.05 \mathrm{~mm}$ width appeared at a load level of $\approx 43 \%$ of their limit strength, which is similar to unstrengthened specimens. For SC-3-0.3 and SC-4-0.3 $0.05 \mathrm{~mm}$, cracks load level was $\approx 55 \%$ of their limit strength, and $\approx 67 \%$ for SC-5-0.5 and SC-6-0.5. Maximum crack width for all strengthened columns at limit strength equaled $0.3-0.4 \mathrm{~mm}$.

Specimens review after tests found no signs of displacements, cracks or adherence loss between columns and jacketing.

Test results of all specimens are summarized in Table 1.

Table 1. Specimens test results

Tabela 1. Wyniki badania próbek

\begin{tabular}{|l|c|c|c|c|}
\hline $\begin{array}{c}\text { Test } \\
\text { specimen }\end{array}$ & $\begin{array}{c}\text { Load at the time } \\
\text { of strengthening } \\
(\mathbf{k N})\end{array}$ & $\begin{array}{c}\text { Experimental } \\
\text { strength } \\
\boldsymbol{N}_{\max } \mathbf{( k N )}\end{array}$ & $\begin{array}{c}\text { Strengthening } \\
\text { efect }\end{array}$ & $\begin{array}{c}\mathbf{0 . 0 5 m m} \\
\text { crack load } \\
\boldsymbol{N}_{\text {crc }}(\mathbf{k N})\end{array}$ \\
\hline C-1 & - & 165.7 & - & 77.7 \\
C-2 & - & 480.5 & $290 \%$ & 205.9 \\
\hline $\begin{array}{l}\text { SC-1-0.0 } \\
\text { SC-2-0.0 }\end{array}$ & - & 460.9 & $278 \%$ & 255.0 \\
\hline $\begin{array}{l}\text { SC-3-0.3 } \\
\text { SC-4-0.3 }\end{array}$ & 51.0 & 441.3 & $266 \%$ & 294.2 \\
\hline $\begin{array}{l}\text { SC-5-0.5 } \\
\text { SC-6-0.5 }\end{array}$ & 88.3 & & & \\
\hline
\end{tabular}

\subsection{Comparison with theoretical calculations}

The limit strength of all specimens was calculated according to Ukrainian design codes $[6,7]$. Concrete stress-strain relation for non-linear analysis was used $[6,8]$. Calculations were performed by solving a system of non-linear equations:

$$
\left\{\begin{array}{l}
N_{1}\left(\aleph, \varepsilon_{c(1)}\right)+N_{2}\left(\aleph^{a d}, \varepsilon_{c(1)}^{a d}\right)-N=0 \\
M_{1}\left(\aleph, \varepsilon_{c(1)}\right)+M_{2}\left(\aleph^{a d}, \varepsilon_{c(1)}^{a d}\right)-M=0
\end{array}\right.
$$

where: $N_{1}\left(\aleph, \varepsilon_{c(1)}\right)$ and $N_{2}\left(\aleph^{a d}, \varepsilon_{c(1)}^{a d}\right)$ - are functions that represent axial forces held by concrete $N_{c}$ and reinforcement $N_{s}$ of the column, and $N_{c}^{a d}$ and $N_{s}^{a d}$ of the jacketing, $M_{1}\left(\aleph, \varepsilon_{c(1)}\right)$, and $M_{2}\left(\aleph^{a d}, \varepsilon_{c(1)}^{a d}\right)$ - are functions that represents moments of forces $N_{c}, N_{s}, N_{c}^{a d}$ and $N_{s}^{a d}$ about the neutral axis in 
the cross section,

$N, M$ - are the compressive force and bending moment that are applied to a column.

System of equations (1) is solved using gradual approximation method $[1,7]$. Calculation results are given in Table 2.

Table 2. Experimental and calculated limit strengths of the test specimens

Tabela 2. Graniczna nośność próbek otrzymana z badań i obliczeń

\begin{tabular}{|l|c|c|c|}
\hline \multicolumn{1}{|c|}{ Test specimen } & $\begin{array}{c}\text { Experimental } \\
\text { strength } \\
\boldsymbol{N}_{\text {max,exp }}(\mathbf{k N})\end{array}$ & $\begin{array}{c}\text { Theoretical } \\
\text { strength } \\
\boldsymbol{N}_{\text {max, }, \text { teor }}(\mathbf{k N})\end{array}$ & $\boldsymbol{N}_{\text {max, } \text {,eor }} / \boldsymbol{N}_{\text {max, exp }}$ \\
\hline $\begin{array}{l}\text { C-1 } \\
\text { C-2 }\end{array}$ & 165.7 & 163.2 & 0.98 \\
\hline $\begin{array}{l}\text { SC-1-0.0 } \\
\text { SC-2-0.0 }\end{array}$ & 480.5 & 434.8 & 0.90 \\
\hline $\begin{array}{l}\text { SC-3-0.3 } \\
\text { SC-4-0.3 }\end{array}$ & 460.9 & 427.8 & 0.93 \\
\hline $\begin{array}{l}\text { SC-5-0.5 } \\
\text { SC-6-0.5 }\end{array}$ & 441.3 & 405.5 & 0.92 \\
\hline
\end{tabular}

As we can see from Table 2, theoretical calculation of unstrengthened columns showed only $2 \%$ deviation from experimental values. Calculation of strengthened columns showed $7-10 \%$ deviation which is acceptable.

\section{Conclusions}

1. RC jacketing is a very effective strengthening method that allowed us to achieve $290 \%$ of strength increase for columns SC-1-0.0 and SC-2-0.0.

2. The limit strength of strengthened columns decreases with the increase of previous loading level. In comparison with SC-1-0.0 and SC-2-0.0 strength of SC-3-0.3 and SC-4-0.3 decreased by 12\%; SC-5-0.5 and SC$6-0.5$ by $24 \%$.

3. Cracks appeared later in columns that were strengthened with bigger initial loading.

4. Crack width at limit strength was the same for all specimens and equaled $0.3-0.4 \mathrm{~mm}$.

5. Strengthened columns appeared to work as monolithic structures. No displacements, cracks or adherence loss between columns and jacketing was noticed.

6. Experimental strength of test specimens was close to calculated values. Maximum deviation was $10 \%$. 


\section{Bibliography}

[1] Bambura A.M., Nemchynov Y.I., Hurkivskyi O.B., Bezbozhna M.S., Dorohova O.V. The main points of the calculation of bearing capacity of concrete and reinforced concrete structures acording to national regulations DBN V.2.6.-98:2009. Building construction: collection of scientific works No. 73. pp. 724-735, 2010 (in Ukrainian).

[2] Blikharskyi Z.Y., Tsarov Y.S., Khmil R.Y., Popovych V.I. Methods of experimental studies of compressed reinforced concrete elements subjected to the short-term eccentrically applied loading. Proceedings of the National University "Lviv Polytechnic" No. 662. pp. 50-54, 2010 (in Ukrainian).

[3] Júlio E.N.B.S., Branco F.A.B., Silva V.D. Reinforced concrete jacketing - interface influence on monotonic loading response. ACI Structural Journal Vol. 102. No. 2. pp. 252257, 2005.

[4] Terianik V.V., Borisov A.O. Strengthening of compressed reinforced concrete columns using jacketing. Housing construction No. 2. pp. 24-25, 2010 (in Russian).

[5] Fardiev R.F., Mustafin I.I. The results of experimental studies of eccentrically compressed elements, strengthened by reinforced concrete jacketing. Collection of articles. Construction industry: yesterday, today, tomorrow. MK-36-10. pp. 105-109, 2010 (in Russian).

[6] DBN V.2.6.-98:2009 Concrete and reinforced concrete structures (in Ukrainian).

[7] DSTU B V.2.6-156:2010 Concrete and reinforced concrete. Design regulations. (in Ukrainian).

[8] EN 1992-1-1:2004 Eurocode 2: Design of concrete structures - Part 1-1: General rules for buildings.

\section{NOŚNOŚĆ ŻELBETOWYCH SŁUPÓW WZMACNIANYCH POD OBCIĄŻENIEM ŻELBETOWĄ OTULINĄ}

\section{Streszczenie}

Stosowanie otuliny żelbetowej (RC) jest powszechną metodą wzmacniania słupów. Projektowanie takiego wzmocnienia wymaga rozważania dodatkowych czynników np. ciężaru konstrukcji przenoszonego przez słup. Głównym celem badań było określenie wpływu tego czynnika. Słupy były wstępnie obciążane do różnych poziomów wytężenia, a następnie wzmacniane i badane do zniszczenia. Wszystkie próbki miały identyczne cechy geometryczne i mechaniczne i były badane jako słupy przegubowo zamocowane i obciążone mimośrodowo. Jako zmienny parametr przyjęto różne poziomy wstępnego obciążenia. Podczas badań mierzono linowe odkształcenia betonu i zbrojenia, ugięcia oraz rozwój rys. Otulina pozwoliła osiągnąć wzrost nośności do 290\%. Nie zauważono żadnych uszkodzeń pomiędzy słupem a otuliną. Nośność wzmocnionego słupa była bliska wartości otrzymanej z modelu analitycznego, a różnica nie przekraczała $10 \%$.

Słowa kluczowe: żelbeton, słupy, wzmacnianie przez otulinę, projektowanie

Przestano do redakcji:30.05.2015

Przyjęto do druku:1.12.2015

DOI: $10.7862 / \mathrm{rb} .2015 .151$ 